\title{
Ceramic tiles waste as replacement material in Portland cement
}

\section{María A. Mas}

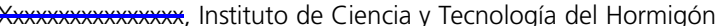

Q1 (ICITECH), Universitat Politècnica de València, Valencia, Spain José Monzó

Instituto de Ciencia y Tecnología del Hormigón (ICITECH), Universitat Politècnica de València, Valencia, Spain Jordi Payá

Instituto de Ciencia y Tecnología del Hormigón (ICITECH), Universitat Politècnica de València, Valencia, Spain

\section{Lucía Reig}

Departamento de Ingeniería Mecánica y Construcción (EMC), Universitat Jaume I, Castelló de la Plana, Spain

María V. Borrachero

列 (ICITECH), Universitat Politècnica de València, Valencia, Spain

The pozzolanic reactivity of real ceramic waste from different tile manufacturing companies was evaluated and its suitability as a partial Portland cement replacement was analysed. The raw material was finely ground and physicochemically characterised using x-ray fluorescence (XRF), x-ray diffraction (XRD), scanning electron microscopy (SEM) and laser analysis particle size distribution (ADL). Percentages of ceramic waste (from 15 wt $\%$ to 50 wt\%) to substitute Portland cement were used to assess this material's pozzolanic behaviour, and samples were cured at $20^{\circ} \mathrm{C}$ for different curing times. pH tests and conductivity measurements were used to evaluate its pozzolanic character, while mortars were utilised to evaluate compressive strength behaviour. The microstructural evolution of the developed binders was assessed in pastes by XRD, thermal analysis, Fourier transform infrared spectroscopy (FTIR) and SEM analyses. A strength gain due to pozzolanic activity was observed after $28 \mathrm{~d}$ and $\mathbf{9 0} \mathrm{d}$ curing. The results prove that mortars with up to $\mathbf{3 5} \mathrm{wt} \%$ of tile ceramic waste comply with the requirements established for fly ash pozzolanic materials.

\section{Introduction}

Portland cement clinker is the dominant binder used in concrete because of an abundance of raw materials, its relatively low cost and its excellent mechanical and durability properties. However, as reported by Meyer (2009), its production process is energy intensive $(850 \mathrm{kcal}$ per kilogramme of clinker) and emits a high level of carbon dioxide emissions to the atmosphere (about a tonne of carbon dioxide per tonne of cement). It has also been estimated that cement companies are responsible for the emission of about two billion tonnes of carbon dioxide per year, which is $6-7 \%$ of the planet's total carbon dioxide emissions (Meyer, 2009). The cement industry is looking for alternatives to overcome these problems and to comply with Kyoto protocol obligations by making more sustainable binders and reusing wastes from other industries. Among the different options analysed, the scientific community has incorporated industrial byproducts such as silica fume, fly ash, ceramic materials, glass and so on into the production of mortars and concretes (Frías et al., 2011; Lavat et al., 2009; Naceri and Hamina, 2009; Payá et al., 2002; Pereira de Oliveira et al., 2012). As explained by Frías et al. (2012) and Payá et al. (1999), the development of cement matrices that contain industrial by-products brings environmental, economic and technological benefits, since it

- avoids the disposal of waste materials and minimises the use of natural resources, which implies energy savings and, therefore, fewer carbon dioxide emissions allows the use of waste to replace higher cost materials

improves some properties of mortars and concretes.

Some of these by-products are ceramic in nature and have been successfully used in concrete and cement production (Ay and Ünal, 2000; Medina et al., 2012, 2013; Reig et al., Q2 2013a, 2014; Shi et al., 2011). Authors such as Medina et al. Q3 (2012a, 2012b, 2013a, 2013b) analysed the feasibility of using ceramic sanitary ware as a partial replacement for natural aggregates in concrete production. Contents of traditional coarse aggregates, ranging from 15 to $25 \mathrm{wt} \%$, were substituted, and the microstructure, physical and mechanical properties, rheological and calorimetric behaviour, gas and water permeability of the developed concrete were analysed. Other types of ceramic waste such as bricks and sanitary ware (Alves et al., 2014), construction and demolition waste (Bezerra Cabral et al., 2010) and electrical insulators (Senthamarai et al., 2011) have 
also been successfully used as aggregates in concrete production. The suitability of other ceramic materials (e.g. red hollow bricks and ceramic tiles) as a source of aluminosilicate in alkali-activated binder production was also proved by Reig Q4 et al. (2013, 2014) and Sun et al. (2013). Similarly, Puertas et al. (2010) proposed the use of ceramic waste as a starting material for Portland cement manufacture while Silva et al. (2008) and Pereira de Oliveira et al. (2012) successfully proved the pozzolanic activity of ceramic materials. Different types of ceramic products (red clay brick waste, glass and tiles) were used by Pereira de Oliveira et al. (2012) to replace 10-40\% Portland cement and $10 \%$ of red clay brick waste was used in the study reported by Silva et al. (2008). Although both studies reported the compressive strength evolution of the developed mortars, they provided very little information on the developed microstructure and the pozzolanic reaction.

As previously explained by Zanelli et al. (2011), the production process of ceramic materials determines the microstructure and phases developed, which greatly influence their potential reactivity. Among the different categories of ceramic products produced (structural products, tiles, sanitary ware, etc.), floor and wall ceramic tiles are produced in different temperaturetime cycles, with peak firing temperatures usually falling within the range $1120-1220^{\circ} \mathrm{C}$ (García Ten, 2005). Global ceramic tile production has increased in recent years from 8581 million $\mathrm{m}^{2}$ in 2009 to 11913 million $\mathrm{m}^{2}$ in 2013 (Stock, 2014). As reported by Stock (2014), Spain is the largest tile producer in the European Union and ranks fifth in global production, with 420 million $\mathrm{m}^{2}$ made in 2013 , which implies $3 \cdot 5 \%$ of world production. It is the second largest exporting country in the world, with 318 million $\mathrm{m}^{2}$ exported $(75.7 \%$ of national production). As reported by Monfort et al. (2011), more than 215 companies related to the manufacturing process of ceramic tiles were registered in Spain in 2008; most (87\%) were located in the Comunidad Valenciana (comprising Valencia, Alicante and Castellón in east Spain), which produced approximately $95 \%$ of the total national production. Ceramic waste is also generated in the construction sector: according to data from

Q5 the Spanish National Institute of Statistics (2013), the construction sector in Spain produced $32.7 \mathrm{Mt}$ tons of waste in 2011, of which about 54\% was ceramics (GdE, 2010).

The objective of this research was to study the recycling of real ceramic waste arising from different tile manufacturing companies in order to produce pozzolanic cement. The properties of the ceramic waste were analysed and its pozzolanic reactivity was evaluated at different curing ages with replacements of various percentages of Portland cement.

\section{Materials and methodology}

\section{Materials}

The ceramic waste used in this study came from the Spanish tile ceramic industry and contained different types of tiles such as wall, stoneware and porcelain stoneware tiles. Portland cement type CEM I 42.5R (containing $4 \cdot 5 \%$ calcium carbonate), partially replaced $(0-50 \mathrm{wt} \%)$ with tile ceramic waste (TCW), was used to prepare pastes and mortars.

As-received TCW was dried in an oven at $100^{\circ} \mathrm{C}$ for $48 \mathrm{~h}$, crushed in a jaw crusher (BB200, Retsch) to obtain a particle size smaller than $2 \mathrm{~mm}$ and ground in a porcelain ball mill (Gabbrielli Mill-2) in alumina media (450 g of waste, 90 balls) for $25 \mathrm{~min}$. The mean particle diameter, determined by laser diffraction (Mastersizer 2000, Malvern Instruments), came close to $17 \cdot 28 \mu \mathrm{m}$, with $90 \% \mathrm{vol}$ of particles $\left(d_{90}\right)$ under $43.02 \mu \mathrm{m}$. As shown in Figure 1, irregularly shaped particles with a smooth surface and sharp edges were observed by scanning electron microscopy (SEM) (JEOL JSM-6300).

Table 1 indicates the chemical composition of the TCW, as determined by x-ray fluorescence (XRF) analysis (Philips Magix Pro). As can be seen in the table, the TCW contained high levels of silicon dioxide and aluminium oxide (79.82 wt $\%$, together with moderate amounts of calcium oxide, iron oxide and potassium oxide. The amorphous content (soluble fraction), determined according to UNE EN 196-2 specifica- Q6 tions, was $60 \mathrm{wt} \%$, which is higher than that determined for red clay brick waste (35 wt\%) (Reig et al., 2013b) and porcelain stoneware tiles (46 wt\%) (Reig et al., 2014).

Mineralogical composition was determined by x-ray diffraction (XRD) (Brucker AXS D8 Advance with $\mathrm{CuK} \alpha$ radiation, $40 \mathrm{kV}$ and $20 \mathrm{~mA}, 2 \theta$ from $5^{\circ}$ to $70^{\circ}$ ). The data in Figure 2 indicate that quartz $\left(\mathrm{Q}, \mathrm{SiO}_{2}\right.$; powder diffraction file (PDF) \#331161) is the major crystalline phase, with mullite (M, $\mathrm{Al}_{6} \mathrm{Si}_{2} \mathrm{O}_{13}$; PDF \#150776), albite (A, $\mathrm{NaAlSi}_{3} \mathrm{O}_{8}$; PDF \#190926), and the calcium magnesium silicate known as

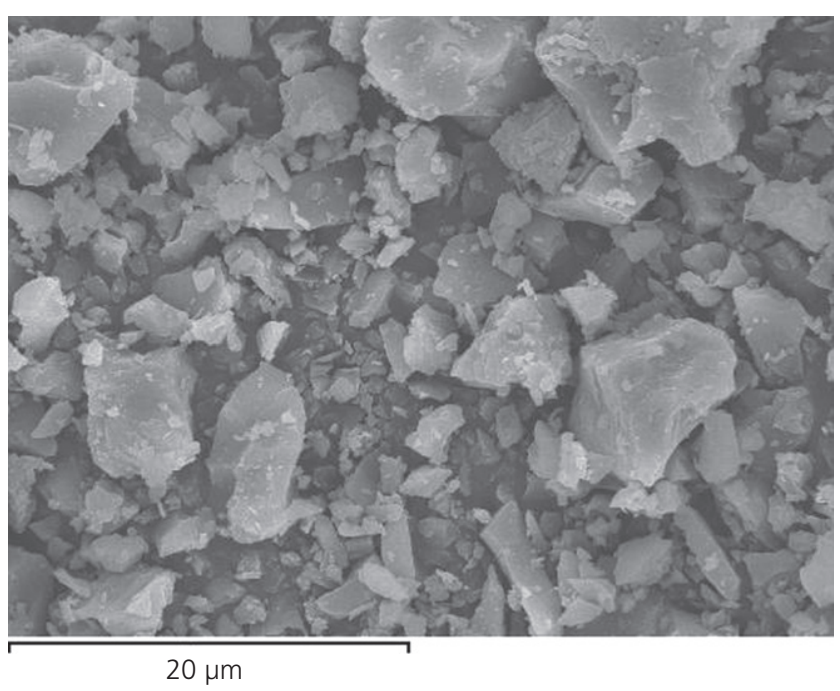

Figure 1. SEM micrograph of ground TCW 


\section{PROOFS}

Sodium oxide $\left(\mathrm{Na}_{2} \mathrm{O}\right)$ : wt $\%$

Magnesium oxide (MgO): wt\%

1.79

Aluminium oxide $\left(\mathrm{Al}_{2} \mathrm{O}_{3}\right)$ : wt $\%$

$18 \cdot 60$

Silicon dioxide $\left(\mathrm{SiO}_{2}\right)$ : $w t \%$

$61 \cdot 22$

Phosphorus pentoxide $\left(\mathrm{P}_{2} \mathrm{O}_{5}\right)$ : wt \%

0.25

Sulfur trioxide $\left(\mathrm{SO}_{3}\right)$ : wt\%

Potassium oxide $\left(\mathrm{K}_{2} \mathrm{O}\right)$ : $w t \%$

0.09

3.33

Calcium oxide ( $\mathrm{CaO})$ : wt\%

$5 \cdot 77$

Titanium dioxide $\left(\mathrm{TiO}_{2}\right): \mathrm{wt} \%$

0.82

Iron oxide $\left(\mathrm{Fe}_{2} \mathrm{O}_{3}\right)$ : wt\%

$5 \cdot 02$

0.22

0.38

Zirconium dioxide $\left(\mathrm{ZrO}_{2}\right)$ : wt\%

$0 \cdot 14$

Barium oxide ( $\mathrm{BaO})$ : wt\%

$0 \cdot 19$

Other

$0 \cdot 70$

Table 1. Chemical composition of tile ceramic waste

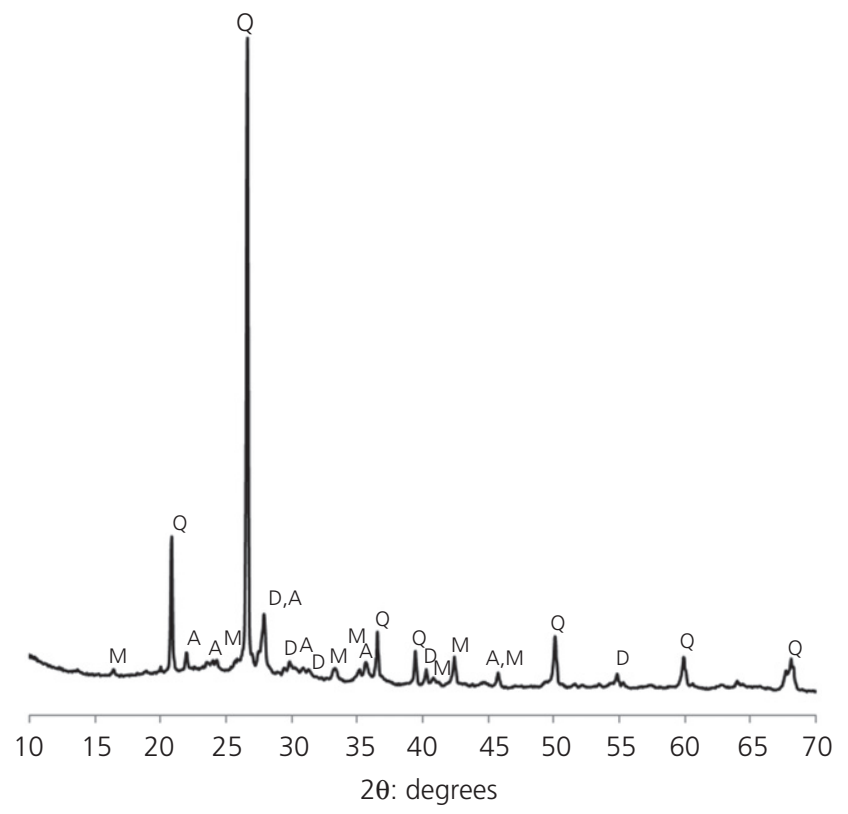

Figure 2. X-ray diffractogram of ground TCW: Q, quartz $\left(\mathrm{SiO}_{2}\right)$; $\mathrm{M}$, mullite $\left(\mathrm{Al}_{6} \mathrm{Si}_{2} \mathrm{O}_{13}\right) ; \mathrm{A}$, albite $\left(\mathrm{NaAlSi}_{3} \mathrm{O}_{8}\right) ; \mathrm{D}$, diopside (CaMg $\left.\left(\mathrm{SiO}_{3}\right)_{2}\right)$

diopside (D, $\mathrm{CaMg}\left(\mathrm{SiO}_{3}\right)_{2}$; PDF \#190239), also present as minor constituents.

\section{$\mathrm{pH}$ and conductivity test method}

The pozzolanic reactivity of ground TCW was assessed by $\mathrm{pH}$ and conductivity tests. As previously described by Tashima et al. (2014), this method consists of monitoring the electrical conductivity and $\mathrm{pH}$ of aqueous lime:pozzolan suspensions mixed in different proportions. Data were taken at $60^{\circ} \mathrm{C}$ for up to $7 \mathrm{~d}$ curing in a micropH2001 $\mathrm{pH}$-meter and a microCM2201 conductimeter (Crison).

The total mass of solid material was kept constant in all the tests $(1 \mathrm{~g})$ and the following lime:pozzolan proportions,

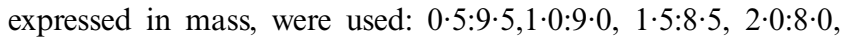
$2 \cdot 5: 7 \cdot 5$ and $3 \cdot 0: 7 \cdot 0$. Suspensions, prepared by adding $50 \mathrm{ml}$ of deionised water to the solid material, were introduced into a $100 \mathrm{ml}$ Erlenmeyer flask. The containers were then tightly capped and placed in a water bath at $60^{\circ} \mathrm{C}$. The different mixes were continuously agitated to facilitate the reaction processes, and electrical conductivity and $\mathrm{pH}$ data were collected every $24 \mathrm{~h}$ up to $7 \mathrm{~d}$. A calcium hydroxide saturated solution was also prepared as the reference (control). The electrical conductivity measurements of the ground TCW $\left(C_{t, \mathrm{poz}}\right)$ suspended in water were also quantified to correct the results with the contribution of ions provided by ceramic waste.

Electrical conductivity curves were produced in terms of loss of conductivity $\left(L_{\mathrm{C}}\right)$, which was calculated as a percentage according to

1. $L_{\mathrm{C}}=\frac{C_{0}-\left(C_{t}-C_{t, \mathrm{poz}}\right)}{C_{0}} \times 100$

where $C_{0}$ is the initial conductivity of the calcium hydroxide suspension before adding pozzolan, $C_{t}$ is the conductivity of the 'lime:pozzolan' mixture at a given time and $C_{t, \mathrm{poz}}$ is the electrical conductivity of the ground TCW (pozzolan) measured in water.

After $7 \mathrm{~d}$ reaction, the suspensions were filtered to separate the solid and liquid fractions. Thermogravimetric analyses (TGA) were used to verify the presence of portlandite and other hydrated products formed by the pozzolanic reaction of ceramic waste. The concentration of calcium ions $\left(\mathrm{Ca}^{+2}\right)$ in the liquid was determined by chemical analysis titrating with 0.05M ethylenediaminetetraacetic acid (EDTA).

\section{Paste and mortar sample preparation}

Paste and mortar samples were prepared using Portland cement (PC) type CEM I 42.5R as the cementitious material and replacing it with different proportions of TCW (15\%, $25 \%, 35 \%$ and $50 \%$ by weight). Paste samples were used to investigate microstructure evolution. For that purpose, the binder $(\mathrm{PC}+\mathrm{TCW})$ was mixed with water $(\mathrm{w} / \mathrm{b}=0 \cdot 5)$ in plastic containers for $4 \mathrm{~min}$, which were then sealed and stored in a thermostatically controlled chamber at $20^{\circ} \mathrm{C}$ at a relative humidity (RH) of $90-95 \%$. Mortars were prepared following the process described in UNE EN 196-1.2005, using 1·0:3·0:0.5 Q8 (binder:sand:water) weight proportions. Siliceous sand with a modulus of fineness of $4 \cdot 36$ and maximum particle size of $2 \mathrm{~mm}$ was used as the aggregate. Specimens were demoulded after being cured for $24 \mathrm{~h}\left(20^{\circ} \mathrm{C}, 90-95 \% \mathrm{RH}\right)$ and were then 
immersed in water with calcium hydroxide until the testing age.

\section{Mortar testing}

The workability of fresh mortars was determined by the flow-

Q9 table test according to UNE 83811:1992 specifications. The compressive strength of mortar specimens was determined following UNE EN 196-1. The compressive strength results are presented here in terms of strength activity index (SAI, in \%) and strength gain (SG, in \%). The SAI represents the ratio of the strength of the mortar with additions to that of the control mortar. SG is defined by Equation 2 and considers the proportion of cement used in the mixtures

2. $\mathrm{SG}=\frac{\left|\mathrm{Cs}_{\mathrm{poz}}-\left(\mathrm{Cs}_{\text {control }} \times \mathrm{cem} \%\right)\right|}{\mathrm{Cs}_{\text {control }} \times \mathrm{cem} \%} \times 100$

where $\mathrm{Cs}_{\mathrm{poz}}$ is the compressive strength of mortar containing TCW, $\mathrm{Cs}_{\text {control }}$ is the compressive strength of the control mortar, and cem $\%$ is the proportion of cement in the mortar with pozzolanic additions (in each unit).

The microstructure of the paste samples was examined by SEM-EDX (JEOL JSM-6300). XRD was used to identify mineralogical phases with the equipment described earlier in the section on materials. The Fourier transform infrared spectroscopy (FTIR) studies were done using a Bruker Tensor 27 Platinum ATR FTIR within the range $400-4000 \mathrm{~cm}^{-1}$. TGA were performed in a Mettler-Toledo TGA850, with a horizontal furnace. Aluminium sealable crucibles $(100 \mu 1)$, with a

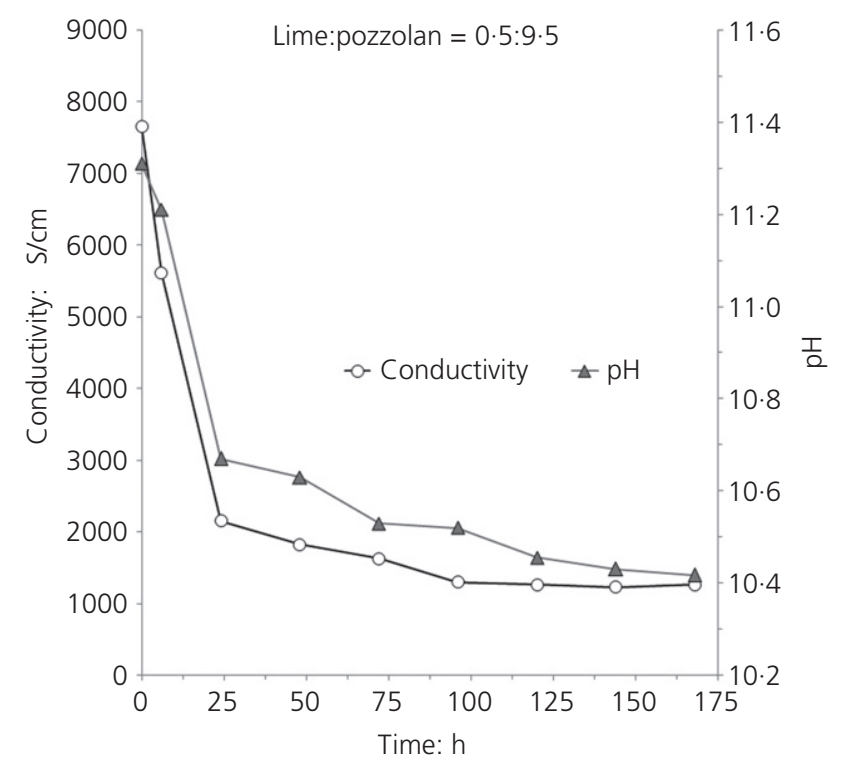

(a) pinhole in the lid to obtain the self-generated atmosphere, were used. The gas flow for the surrounding atmosphere was $75 \mathrm{ml} /$ min of nitrogen and the test was performed at a heating rate of $10^{\circ} \mathrm{C} / \mathrm{min}$ within the temperature range $35-600^{\circ} \mathrm{C}$.

\section{Results and discussion}

$\mathrm{pH}$ and conductivity test results

The curves of conductivity and $\mathrm{pH}$ values for lime:pozzolan concentrations of $0 \cdot 5: 9 \cdot 5$ and 3·0:7.0 are plotted in Figure 3. As can be seen, the conductivity and $\mathrm{pH}$ values rapidly reduced in the mixtures that contained small amounts of lime (Figure 3(a)), which indicates that the calcium and hydroxide ions $\left(\mathrm{Ca}^{2+}\right.$ and $\left.\mathrm{OH}^{-}\right)$of the dissolved lime were consumed by ceramic waste to generate cementitious products that precipitate. The 3:0:7.0 suspension, with a larger amount of lime, became saturated in calcium hydroxide from the very beginning. Despite TCW reacting with the lime dissolved through the pozzolanic reaction and the amount of ions in solution reducing, dissolution of new solid lime occurred. This was the reason for the slight variation noted in the conductivity and $\mathrm{pH}$ values in Figure 3(b) since, although the hydroxide ions in the solution were consumed by TCW, new solid lime was always dissolved.

Figure 4 shows the evolution of loss of conductivity with time for the different lime:pozzolan concentrations in the solutions tested at $60^{\circ} \mathrm{C}$. The suspensions that contained the smallest amounts of calcium hydroxide $(0 \cdot 5: 9 \cdot 5,1 \cdot 0: 9 \cdot 0,1 \cdot 5: 8 \cdot 5$ and $2 \cdot 0: 8 \cdot 0)$ showed significant loss of electrical conductivity (higher than $20 \%$ ), which was attributed to the consumption

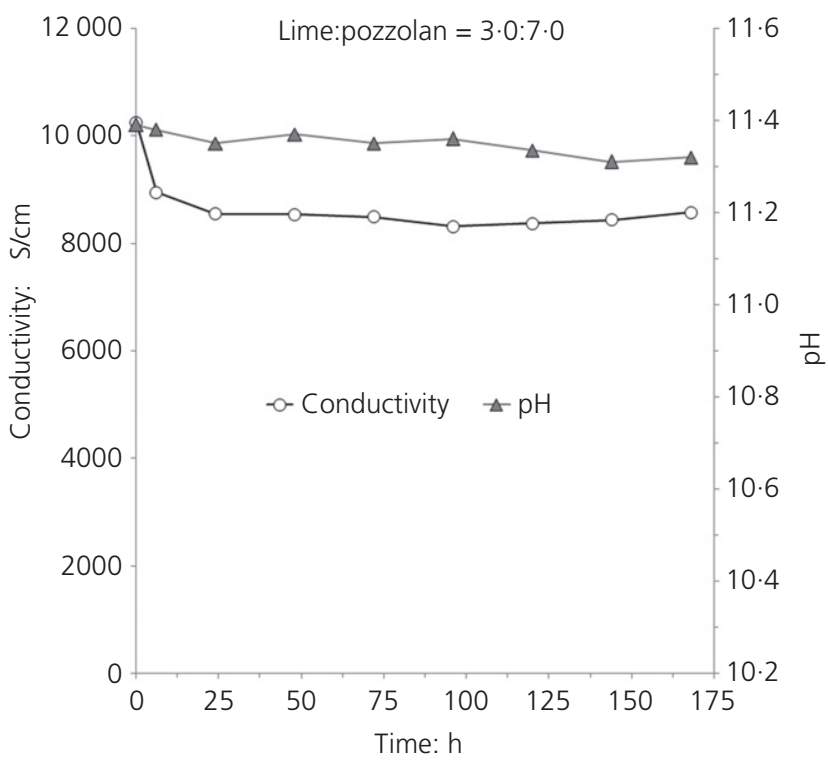

(b)

Figure 3. Electrical conductivity measurements and $\mathrm{pH}$ values for lime:pozzolan suspensions of 0.5:9.5 (a) and 3·0:7·0 (b) 


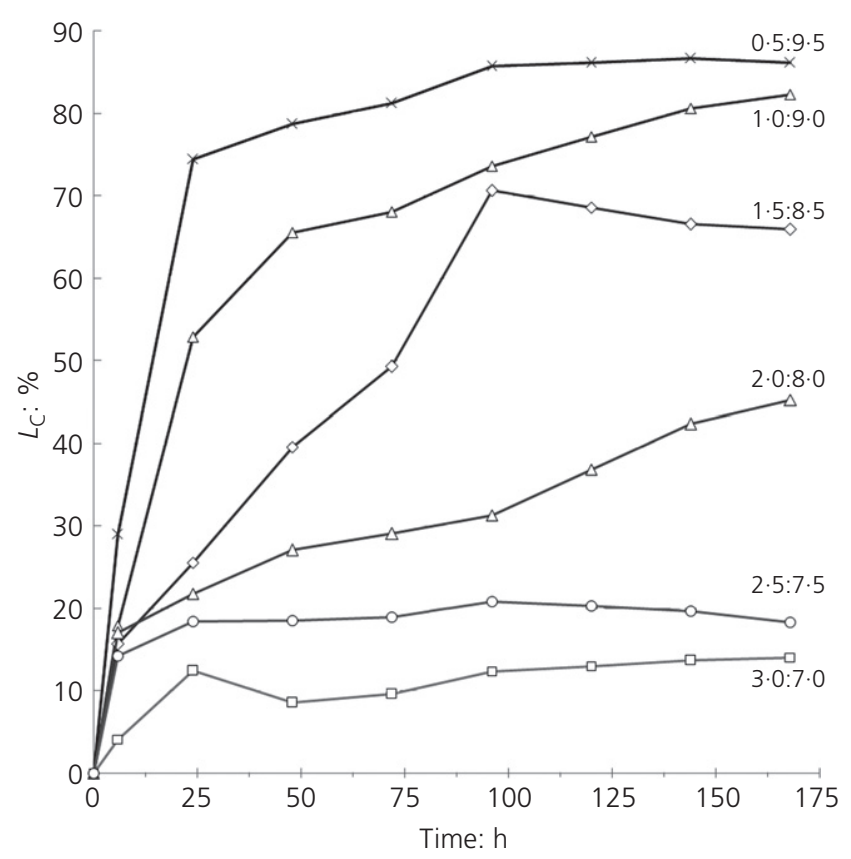

Figure 4. Loss of electrical conductivity, tested at $60^{\circ} \mathrm{C}$, for different lime:pozzolan concentrations

of calcium and hydroxide ions $\left(\mathrm{Ca}^{2+}\right.$ and $\left.\mathrm{OH}^{-}\right)$of lime by the TCW. On the contrary, no significant variation in electrical conductivity values was observed in the samples that contained greater calcium hydroxide $\left(\mathrm{Ca}(\mathrm{OH})_{2}\right)$ additions. This indicates that the ions were not completely consumed due to the low reactivity presented by the TCW at early curing ages. According to the method proposed by Tashima et al. (2014) to assess the pozzolanic reaction rate, suspensions $2 \cdot 5: 6 \cdot 5$ and $3 \cdot 0: 7 \cdot 0$ were saturated in calcium hydroxide since the loss of the conductivity values recorded after $7 \mathrm{~d}$ of testing was lower than $30 \%$ and the $\mathrm{pH}$ values reduced by less than $0 \cdot 15$ units. The results obtained when marking the lime:pozzolan proportion that yielded unsaturation at the testing temperature in the classification diagram provided by Tashima et al. (2014) showed that the reactivity of TCW was low compared to that presented by rice husk ash and silica fume, these being the pozzolanic materials used to develop the pozzolanic reactivity assessment method.

\section{Mortar workability}

The workability of the mortars containing TCW was similar to that presented by the control mortar (with no TCW) and all the values were close to $155 \pm 5 \mathrm{~mm}$ regardless of the amount of TCW added. These results are close to those previously reported by Pereira de Oliveira et al. (2012), who did not observe a significant reduction in the workability of mortars when incorporating TCW and red clay brick waste $(4.5 \%$ and $7 \cdot 3 \%$ respectively in samples that contained $40 \%$ ceramic powder). Although a greater specific surface and porous additions usually require larger amounts of water, this was not the case for TCW, which was attributed to the smooth surface and low porosity of the ceramic particles.

\section{Compressive strength of mortars}

Table 2 summarises the compressive strength results for the mortars with increasing TCW additions, cured for 3-90 d. Although a significant reduction in strength with increasing TCW contents was observed at short curing ages ( $3 \mathrm{~d}$ and $7 \mathrm{~d}$ ), the values came closer to that of the control mortar after curing for $90 \mathrm{~d}$. This behaviour was consistent with the $\mathrm{pH}$ and conductivity test results, and corroborated the low level of reactivity of TCW, which was enhanced at long curing ages.

The SAI results are shown in Figure 5. The obtained results meet the specifications set out in UNE EN 196-1, and were

\begin{tabular}{|c|c|c|c|c|}
\hline \multirow{2}{*}{$\begin{array}{l}\text { TCW: } \\
\text { wt } \%\end{array}$} & \multicolumn{4}{|c|}{ Compressive strength: $\mathrm{MPa}$} \\
\hline & $3 d$ & $7 d$ & $28 d$ & $90 \mathrm{~d}$ \\
\hline 0 & $44.00 \pm 0.58$ & $47 \cdot 19 \pm 1 \cdot 10$ & $51 \cdot 02 \pm 1 \cdot 84$ & $55 \cdot 48 \pm 2 \cdot 01$ \\
\hline 15 & $32 \cdot 11 \pm 1 \cdot 49$ & $43 \cdot 36 \pm 1 \cdot 13$ & $45 \cdot 30 \pm 1 \cdot 79$ & $53 \cdot 13 \pm 2 \cdot 10$ \\
\hline 25 & $32 \cdot 21 \pm 0 \cdot 86$ & $38.46 \pm 1.02$ & $45 \cdot 07 \pm 1 \cdot 58$ & $50 \cdot 48 \pm 2 \cdot 37$ \\
\hline 35 & $29 \cdot 02 \pm 0.85$ & $34 \cdot 30 \pm 0 \cdot 71$ & $40 \cdot 15 \pm 1 \cdot 41$ & $49 \cdot 83 \pm 1 \cdot 89$ \\
\hline 50 & $19 \cdot 09 \pm 0 \cdot 49$ & $24 \cdot 63 \pm 0.80$ & $33 \cdot 82 \pm 0.84$ & $40 \cdot 20 \pm 0 \cdot 92$ \\
\hline
\end{tabular}

Table 2. Evolution of compressive strength of mortars with TCW additions, cured at $20^{\circ} \mathrm{C}$ for $3-90 \mathrm{~d}$

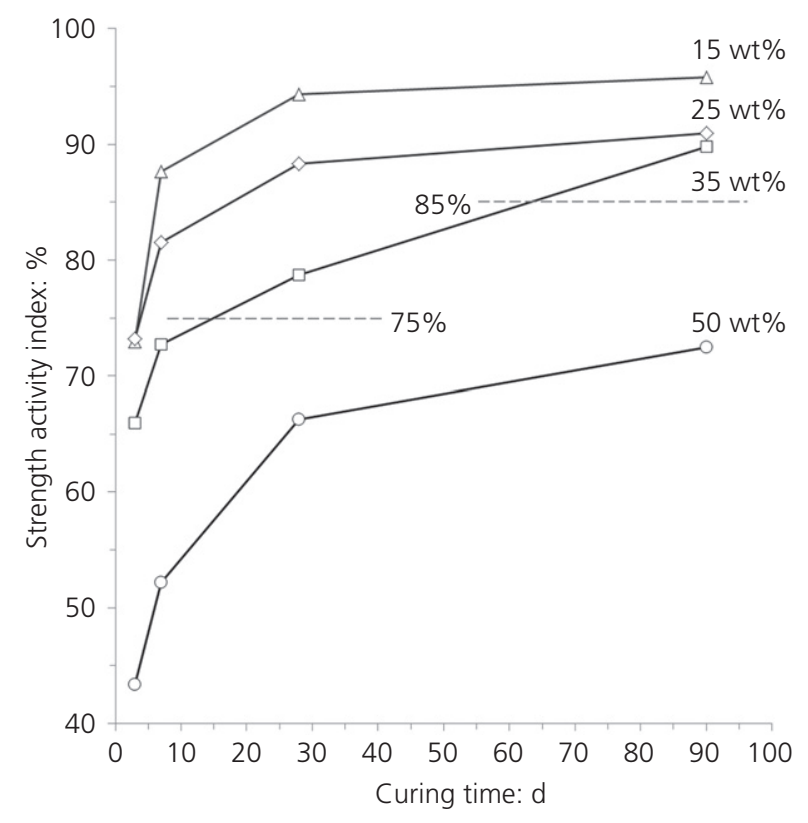

Figure 5. Strength activity index of mortars with TCW additions cured at $20^{\circ} \mathrm{C}$ for $3-90 \mathrm{~d}$ 


\section{PROOFS}

higher than $75 \%$ and $85 \%$ in the mortars that contained $25 \%$ TCW cured for $28 \mathrm{~d}$ and $90 \mathrm{~d}$ respectively. The SAI values Q10 improved with curing time and came closer to after $90 \mathrm{~d}$ curing. This was attributed to the enhanced reaction between pozzolan and portlandite generated during Portland cement hydration. Although the low reactivity of TCW

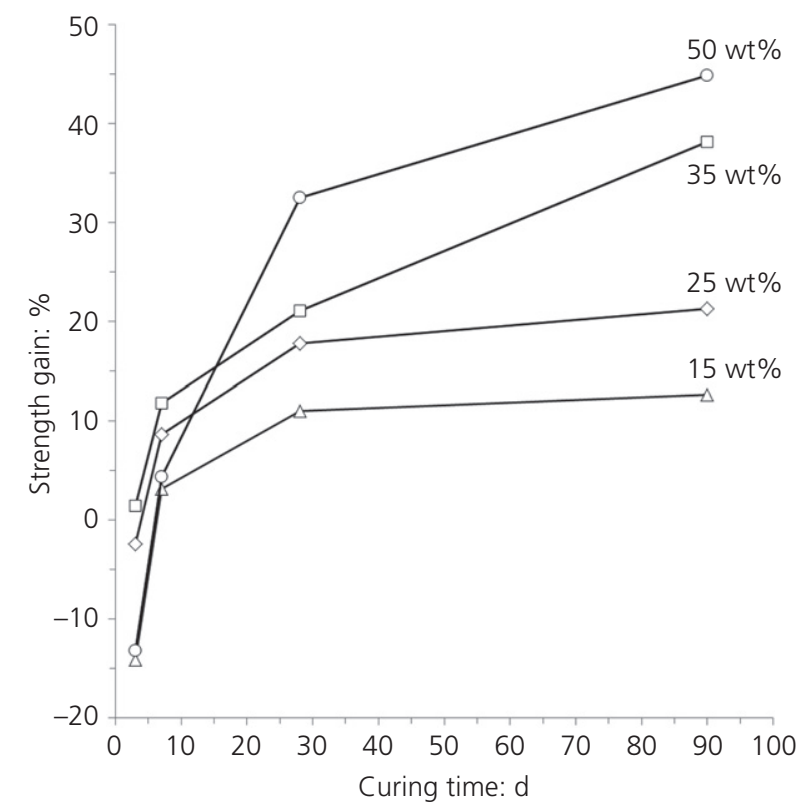

Figure 6. Strength gain index of mortars with TCW additions cured at $20^{\circ} \mathrm{C}$ for $3-90 \mathrm{~d}$

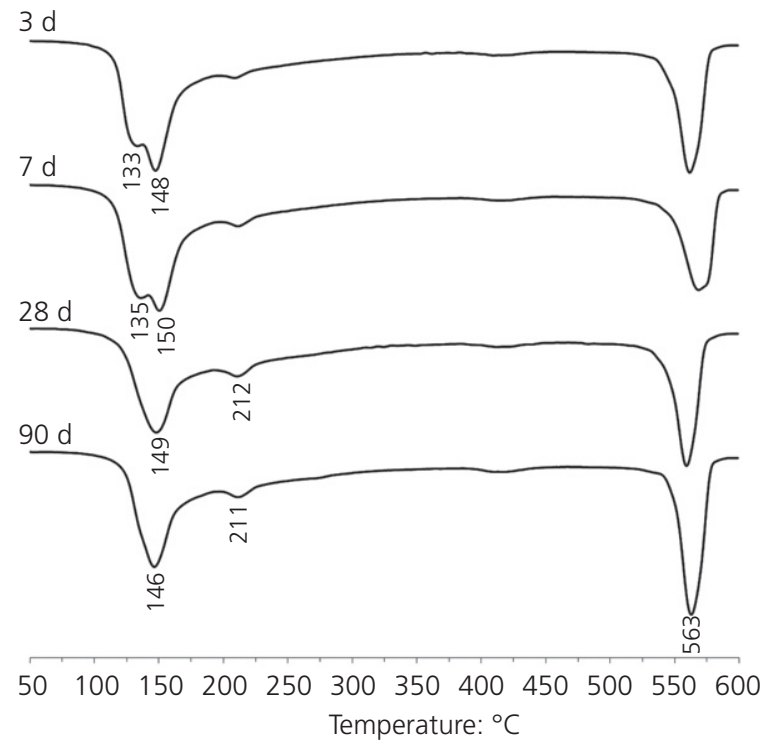

(a)

Figure 7. DTG curves of pastes cured for $3-90 \mathrm{~d}$ at $20^{\circ} \mathrm{C}$ :

(a) control; (b) $50 \mathrm{wt} \% \mathrm{TCW}$ observed at early curing ages makes these materials inadvisable in applications where speed of construction is required, the mechanical requirements set out in fly ash regulations can be satisfied after $28 \mathrm{~d}$ curing by replacing up to $35 \mathrm{wt} \%$ of Portland cement with TCW. This, together with the geographic proximity between Spanish ceramic tile and Portland cement manufacturing companies, makes TCW a potential alternative as a pozzolanic admixture. This would result in environmental and economic advantages, allowing waste that would otherwise be landfilled to be reused.

Similar results were reported by Pereira de Oliveira et al. (2012), who did not observe significant compressive strength differences among mortars that contained brick, tiles, amber and green glass waste as pozzolanic admixtures. Only the mortar with brick powder did not follow the minimum SAI established at $90 \mathrm{~d}$ in UNE EN 196-1 (85\%), which was attributed to its production process as it did not result in a structure with potential pozzolanic reactivity.

Figure 6 shows the strength gains of mortars containing different percentages of TCW $(15-50 \mathrm{wt} \%)$ cured at $20^{\circ} \mathrm{C}$ for up to $90 \mathrm{~d}$. Although the compressive strength results reduced with increasing TCW additions (Table 2), an excellent contribution of pozzolanic addition to the mechanical properties was observed after $28 \mathrm{~d}$ curing, which became more significant with increasing TCW additions. These results agree with those reported by-Heidari at. (2013) for concrete produced Q11 using ground ceramic tile waste as a substitute for Portland cement (0-40 wt \%). As described by (2013), Q12

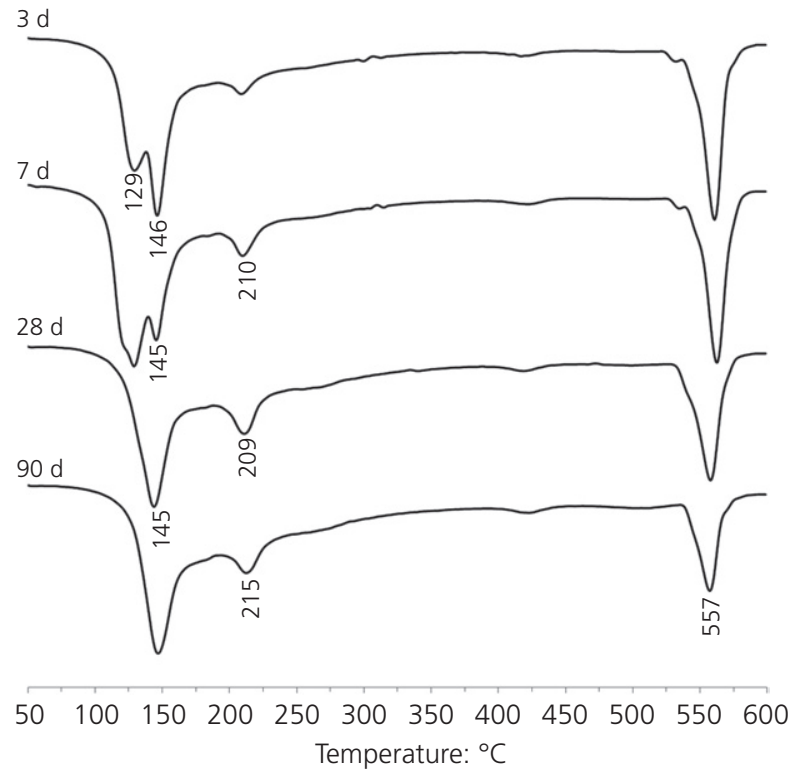

(b) 


\section{PROOFS}

\begin{tabular}{|c|c|c|c|c|c|c|c|c|c|c|c|c|c|c|c|c|}
\hline \multirow{3}{*}{$\begin{array}{l}\text { TCW: } \\
\text { wt\% }\end{array}$} & \multicolumn{16}{|c|}{ Component: wt\% } \\
\hline & \multicolumn{4}{|c|}{$3 \mathrm{~d}$ curing } & \multicolumn{4}{|c|}{$7 \mathrm{~d}$ curing } & \multicolumn{4}{|c|}{$28 \mathrm{~d}$ curing } & \multicolumn{4}{|c|}{$90 \mathrm{~d}$ curing } \\
\hline & TWL & $\mathrm{CH}$ & $\mathrm{H}$ & $\mathrm{FL}$ & TWL & $\mathrm{CH}$ & $\mathrm{H}$ & $\mathrm{FL}$ & TWL & $\mathrm{CH}$ & $\mathrm{H}$ & $\mathrm{FL}$ & TWL & $\mathrm{CH}$ & $\mathrm{H}$ & $\mathrm{FL}$ \\
\hline 0 & $17 \cdot 8$ & $3 \cdot 2$ & $14 \cdot 6$ & & $18 \cdot 8$ & $3 \cdot 2$ & $15 \cdot 6$ & & $18 \cdot 2$ & $3 \cdot 2$ & 14.9 & & $19 \cdot 1$ & $3 \cdot 7$ & $15 \cdot 4$ & \\
\hline 15 & $16 \cdot 1$ & $2 \cdot 8$ & $13 \cdot 3$ & $-2 \cdot 0$ & $17 \cdot 3$ & $2 \cdot 8$ & $14 \cdot 6$ & $-3 \cdot 1$ & $16 \cdot 5$ & $2 \cdot 6$ & 13.9 & $5 \cdot 4$ & $17 \cdot 4$ & $2 \cdot 9$ & $14 \cdot 6$ & \\
\hline 25 & $15 \cdot 0$ & $2 \cdot 5$ & $12 \cdot 5$ & -4.9 & $16 \cdot 5$ & $2 \cdot 8$ & $13 \cdot 7$ & $-19 \cdot 8$ & $15 \cdot 9$ & $2 \cdot 5$ & $13 \cdot 4$ & $-4 \cdot 4$ & $16 \cdot 3$ & $2 \cdot 4$ & $13 \cdot 9$ & $15 \cdot 1$ \\
\hline 35 & $14 \cdot 4$ & $2 \cdot 5$ & 11.9 & $-19 \cdot 6$ & $14 \cdot 4$ & $2 \cdot 4$ & $12 \cdot 1$ & $-15 \cdot 9$ & $14 \cdot 3$ & $2 \cdot 1$ & $12 \cdot 1$ & $-1 \cdot 8$ & $15 \cdot 3$ & 1.5 & $13 \cdot 8$ & $37 \cdot 0$ \\
\hline 50 & $11 \cdot 7$ & $2 \cdot 0$ & 9.7 & $-22 \cdot 6$ & $13 \cdot 3$ & 1.9 & $11 \cdot 3$ & $-24 \cdot 1$ & $12 \cdot 5$ & 1.5 & $11 \cdot 0$ & $-6 \cdot 2$ & $13 \cdot 0$ & 0.9 & $12 \cdot 1$ & 48.5 \\
\hline
\end{tabular}

Table 3. Results obtained after TGA: TWL, total weight loss;

$\mathrm{CH}$, water loss attributed to decomposition of portlandite;

$\mathrm{H}$, percentage of hydrates originated during hydration;

$\mathrm{FL}$, fixed lime

the addition of up to $20 \mathrm{wt} \%$ ceramic powder did not considerably affect compressive strength behaviour, with average decreases of $14.60 \%$ and $1.45 \%$ recorded after $7 d$ and $90 \mathrm{~d}$ curing respectively.

\section{Microstructural studies}

\section{Thermogravimetric analysis}

Figure 7 shows the TGA derivate curves (DTG) of the control paste (Figure 7(a)) and the $50 \mathrm{wt} \%$ TCW paste (Figure 7(b)) cured for 3, 7, 28 and 90 d. According to Payá et al. (2003), the first and second peaks appearing in the diagram overlap within the $100-180^{\circ} \mathrm{C}$ region, and are attributed to the dehydration of calcium silicate hydrates $(\mathrm{CSH})$ and ettringite (AfT). The peak centred at $180-240^{\circ} \mathrm{C}$ corresponds to the dehydration of calcium aluminate hydrates and calcium aluminosilicate hydrates (CAH and $\mathrm{CASH}$ ), while the peak appearing at $520-580^{\circ} \mathrm{C}$ is due to dehydroxylation of portlandite. As expected, the intensity of the last band was stronger in the control paste and diminished with TCW content, which was attributed to the dilution of Portland cement and pozzolanic effects. While this band increased with curing time in the control paste, it progressively decreased with curing age in the samples that contained TCW because of the pozzolanic reaction that occurred between the ceramic waste and portlandite.

Table 3 summarises the main quantitative data obtained after TGA; that is, total weight loss (TWL), water loss attributed to the decomposition of portlandite $(\mathrm{CH})$, the percentage of hydrates originated during the hydration process $(\mathrm{H}$, calculated as the difference between TWL and dehydroxylation of portlandite) and fixed lime (FL). The percentage of fixed lime was determined according to

3. $\mathrm{FL}=\frac{\mathrm{CH}_{\mathrm{c}} \times \mathrm{cem} \%-\mathrm{CH}_{\mathrm{poz}}}{\mathrm{CH}_{\mathrm{c}} \times \mathrm{cem} \%} \times 100$ in which $\mathrm{CH}_{\mathrm{c}}$ is the lime (portlandite) present in the control paste for a given curing time, $\mathrm{CH}_{\mathrm{poz}}$ is the lime in the paste with TCW addition at the same curing age and cem $\%$ is the proportion of cement in the paste with pozzolanic additions.

As shown in Figure 8, negative fixed lime values were obtained at early curing ages which, as explained by $\mathrm{Cyr}$ et al. (2005) and Payá et al. (2003), were attributed to the particle effect that prevailed over the pozzolanic reaction. According to Cyr et al. (2005), this effect accelerated Portland cement hydration due to heterogeneous nucleation, since

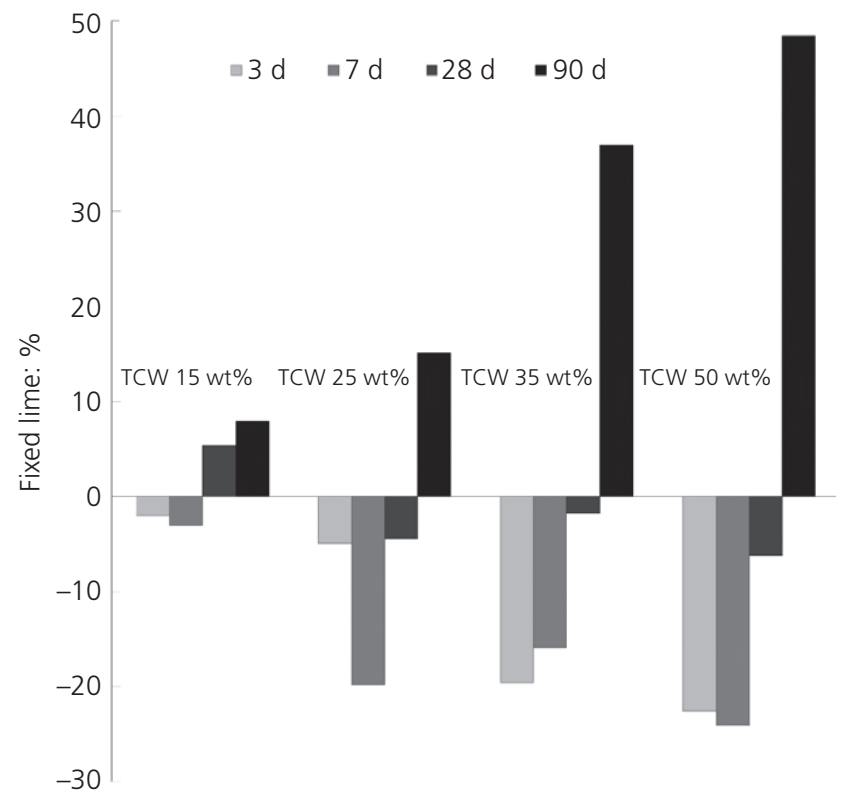

Figure 8. Fixed lime content in pastes with $\mathrm{TCW}$ cured at $20^{\circ} \mathrm{C}$ for 3-90 d 


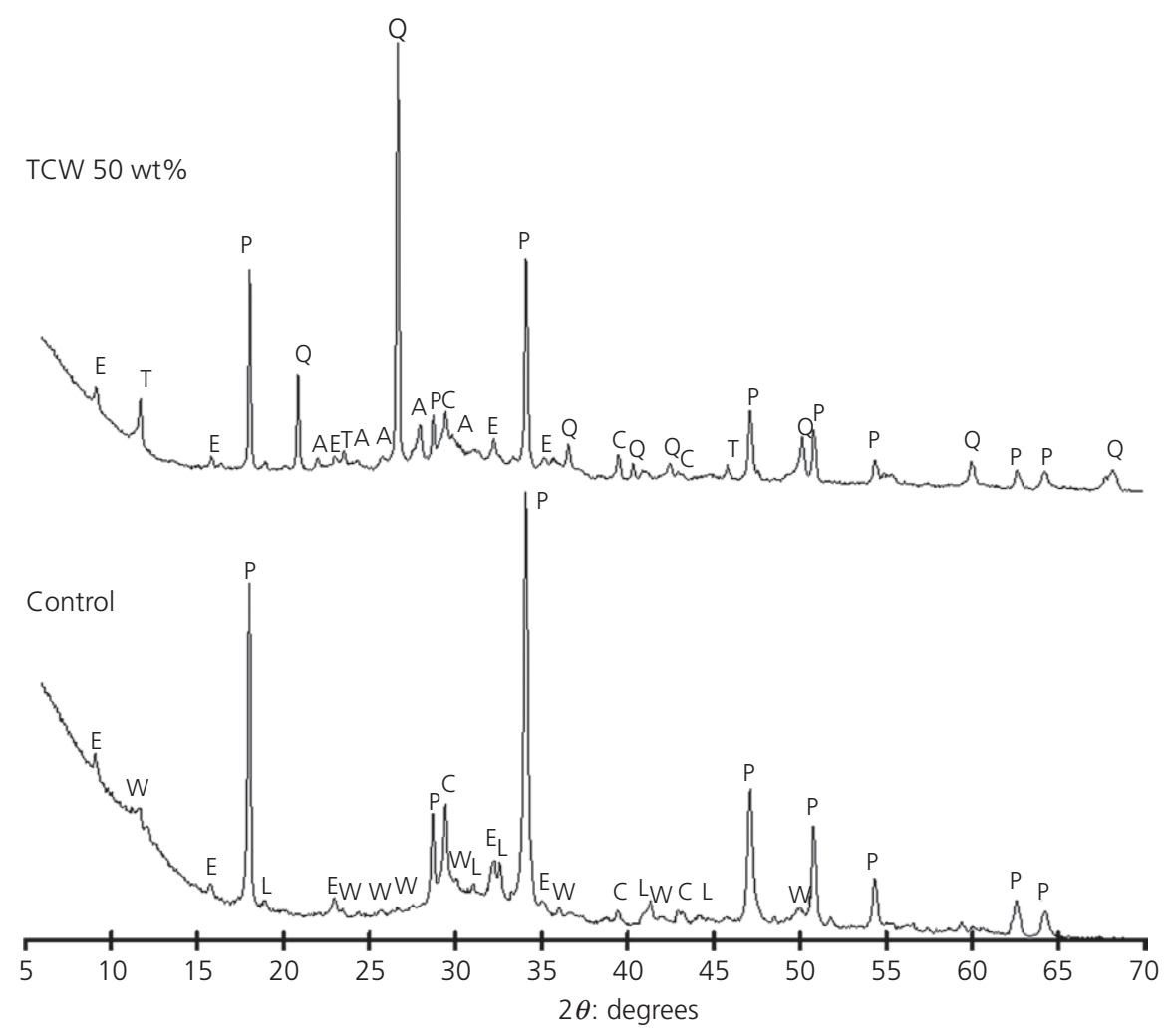

Figure 9. XRD patterns of control and $50 \mathrm{wt} \% \mathrm{TCW}$ pastes cured at $20^{\circ} \mathrm{C}$ for $28 \mathrm{~d}$ : Q, quartz $\left(\mathrm{SiO}_{2}\right)$; $\mathrm{E}$, ettringite $\left(\mathrm{Ca}_{6} \mathrm{Al}_{2}\left(\mathrm{SO}_{4}\right)_{3}(\mathrm{OH})_{12} \cdot 26 \mathrm{H}_{2} \mathrm{O}\right) ; \mathrm{T}$, hydrotalcite $\left(\mathrm{Mg}_{6} \mathrm{Al}_{2} \mathrm{CO}_{3}(\mathrm{OH})_{16}\right.$.
4($\left.\left(\mathrm{H}_{2} \mathrm{O}\right)\right) ; \mathrm{P}$, portlandite $\left(\mathrm{Ca}(\mathrm{OH})_{2}\right) ; \mathrm{A}$, albite $\left(\mathrm{NaAlSi}_{3} \mathrm{O}_{8}\right) ; \mathrm{C}$, calcite $\left(\mathrm{CaCO}_{3}\right) ; \mathrm{W}$, wollastonite $\left(\mathrm{CaSiO}_{3}\right)$; L, larnite $\left(\beta-\mathrm{Ca}_{2} \mathrm{SiO}_{4}\right)$

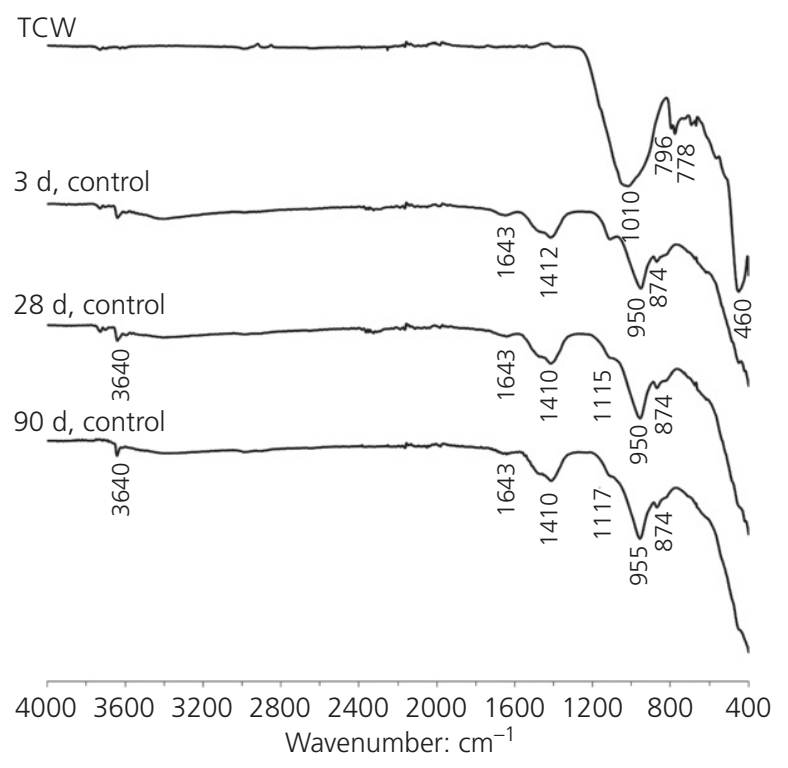

(a)

Figure 10. FTIR spectra of the TCW and pastes cured at $20^{\circ} \mathrm{C}$ for 3-90 d: (a) control; (b) 50 wt\% TCW

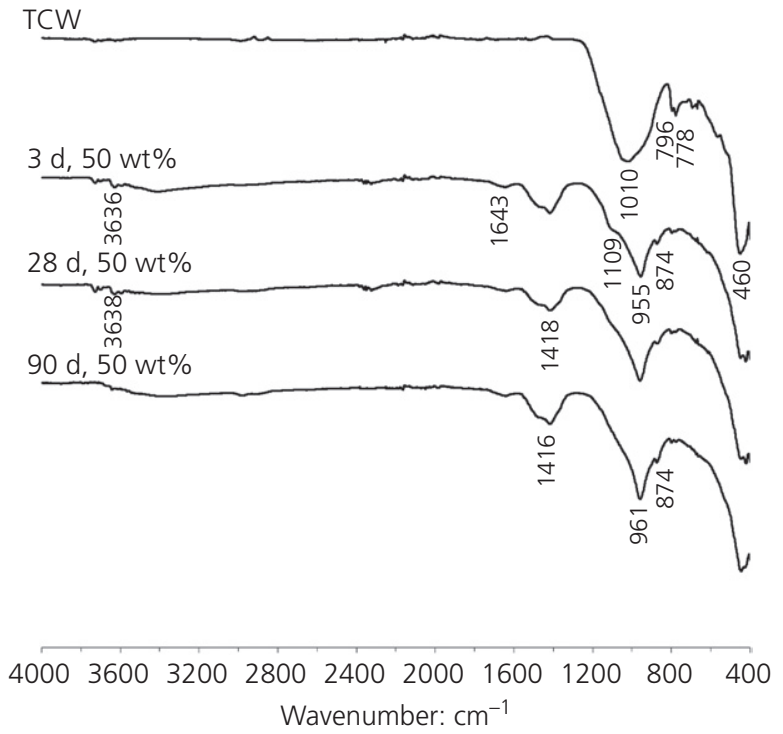

(b) 


\section{PROOFS}

TCW particles provided an extra surface upon which the first hydration products to form could be deposited, thus leaving more free area to continue cement hydration. Then, the cement hydrated faster with increasing ceramic waste contents, producing more negative values. These rates progressively increased to become positive after $90 \mathrm{~d}$ curing, given the consumption of portlandite by ceramic waste in the pozzolanic reaction.

\section{X-ray diffraction studies}

Figure 9 shows the XRD patterns for the control paste and the paste with $50 \mathrm{wt} \% \mathrm{TCW}$, both cured for $28 \mathrm{~d}$. Portlandite $\left(\mathrm{P}, \mathrm{Ca}(\mathrm{OH})_{2}\right.$, PDF \#040733) was the main phase detected in the control paste, together with other minor compounds such as ettringite $\left(\mathrm{E}, \mathrm{Ca}_{6} \mathrm{Al}_{2}\left(\mathrm{SO}_{4}\right)_{3}(\mathrm{OH})_{12}\right.$. $26 \mathrm{H}_{2} \mathrm{O}$, PDF \#411451) and calcite $\left(\mathrm{C}, \mathrm{CaCO}_{3}, \mathrm{PDF}\right.$ $\# 050586$ ). The latter was due to the presence of a limestone filler in the Portland cement composition, which is corroborated by the corresponding peak registered in the paste that contained $50 \mathrm{wt} \%$ TCW, whose intensity diminished due to the dilution effect. Traces of other phases, such as dicalcium silicate larnite ( $\left.\mathrm{L}, \beta-\mathrm{Ca}_{2} \mathrm{SiO}_{4}, \mathrm{PDF} \# 330302\right)$ and calcium silicate wollastonite (W, $\left.\mathrm{CaSiO}_{3}, \mathrm{PDF} \# 100489\right)$, were also detected.

In agreement with the TGA results, the intensities of peaks on the XRD spectrum attributed to portlandite, calcite and ettringite were less for the $50 \mathrm{wt} \% \mathrm{TCW}$ paste than for the control paste. The main crystalline phases corresponding to the ceramic residue, such as quartz $\left(\mathrm{Q}, \mathrm{SiO}_{2}, \mathrm{PDF} \# 331161\right)$ and albite (A, NaAlSi ${ }_{3} \mathrm{O}_{8}, \mathrm{PDF} \# 090466$ ), were also identified in the pastes that contained TCW, along with traces of carboaluminate hydrotalcite $\left(\mathrm{T}, \mathrm{Mg}_{6} \mathrm{Al}_{2} \mathrm{CO}_{3}(\mathrm{OH})_{16} \cdot 4\left(\mathrm{H}_{2} \mathrm{O}\right), \quad \mathrm{PDF}\right.$ \#141191).

\section{Fourier transform infrared spectroscopy}

The FTIR spectra of the control paste and the $50 \mathrm{wt} \% \mathrm{TCW}$ paste cured at $20^{\circ} \mathrm{C}$ for 3-90 d are plotted in Figures 10 (a) and 10(b) respectively. The FTIR spectrum of the TCW is included in the figures for reference purposes: the ceramic material presented a main band within the $1200-950 \mathrm{~cm}^{-1}$ region, centred at $1009 \mathrm{~cm}^{-1}$, together with a signal at $460 \mathrm{~cm}^{-1}$ and lower intensity bands at $796-778 \mathrm{~cm}^{-1}$ (double peak). These bands were attributed to the asymmetric stretching vibrations of $\mathrm{Si}-\mathrm{O}$ and Al-O bonds (Frías et al., 2011) and were distinguished in all the pastes that contained TCW, which denoted the presence of unreacted TCW.

As reported by $\mathrm{Yu}$ et al. (1999), the bands that appeared within the $950-1100 \mathrm{~cm}^{-1}$ region in all the hydrated pastes are typically originated by the $\mathrm{Si}-\mathrm{O}$ stretching vibrations of newly formed calcium silicate hydrates. The bands that arose at $1630 \mathrm{~cm}^{-1}$ and $3450 \mathrm{~cm}^{-1}$ were attributed to the bending $(\mathrm{H}-\mathrm{O}-\mathrm{H})$ and stretching vibrations $(-\mathrm{OH})$ of the hydroxyl groups in hydrated products. These bands appeared together with the sharp peak that originated at $3640 \mathrm{~cm}^{-1}$, which also corresponded to $-\mathrm{OH}$ stretching vibrations (Parande et al., Q13 2011). The evolution of this band was linked to that attributed to calcium hydroxide in the thermogravimetric diagrams (the $520-580^{\circ} \mathrm{C}$ region in Figure 7), which persisted after $90 \mathrm{~d}$ of curing and registered decreasing intensities with increasing TCW contents.

As explained by Lee and Li (2010), the bands that appeared at $1400-1500 \mathrm{~cm}^{-1}$, together with that centred at $874-714 \mathrm{~cm}^{-1}$, were associated with carbonate $\left(\mathrm{CO}_{3}^{-2}\right)$ asymmetric vibrations. In agreement with the XRD results, these bands did not appear in the raw material (TCW), but were clearly distinguished in all the hydrated pastes, being attributed to the calcium carbonate filler in the Portland cement used.
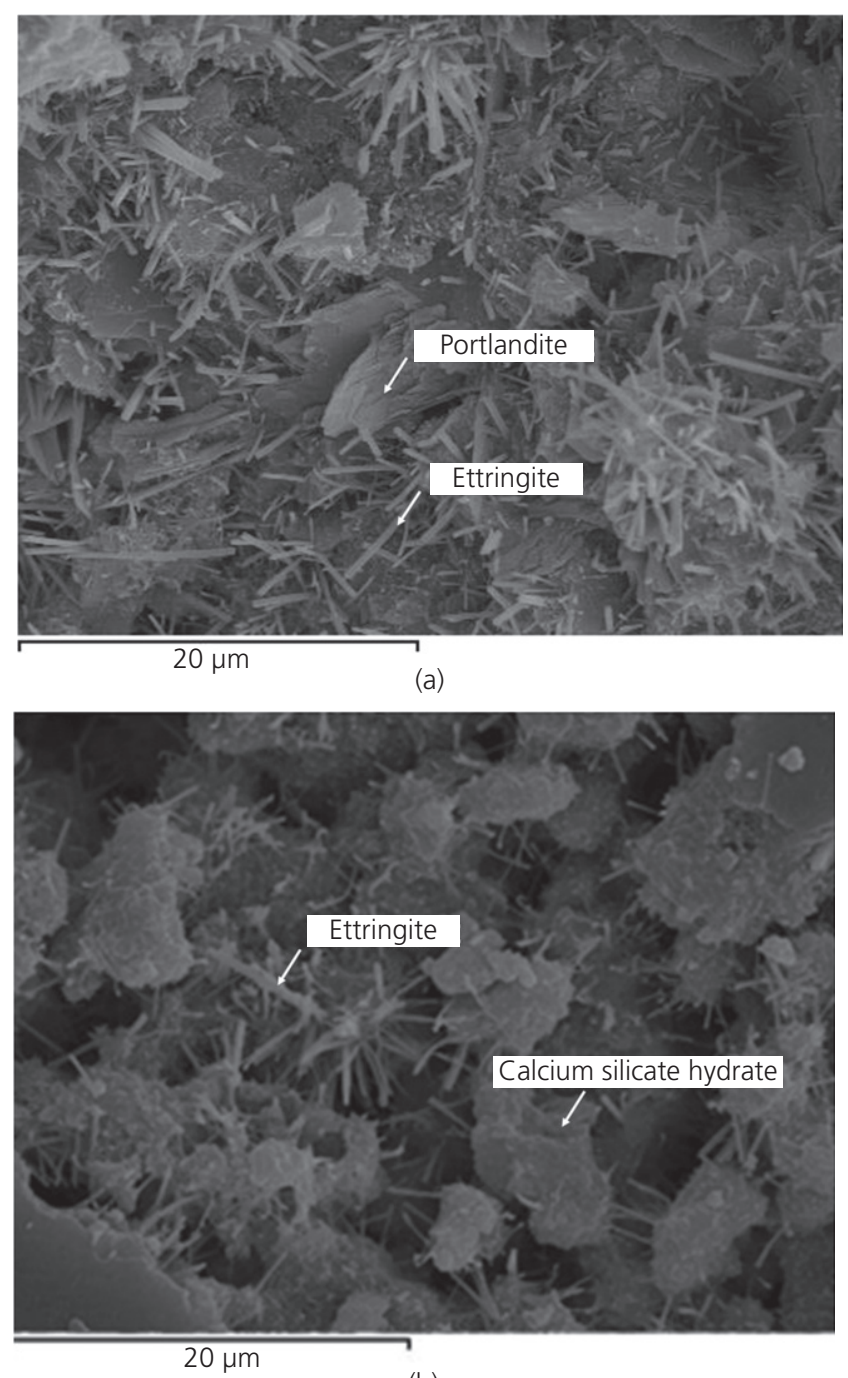

(b)

Figure 11. SEM images of pastes cured at $20^{\circ} \mathrm{C}$ for $28 \mathrm{~d}$ : (a) 25 wt\% TCW; (b) 50 wt\% TCW 


\section{PROOFS}
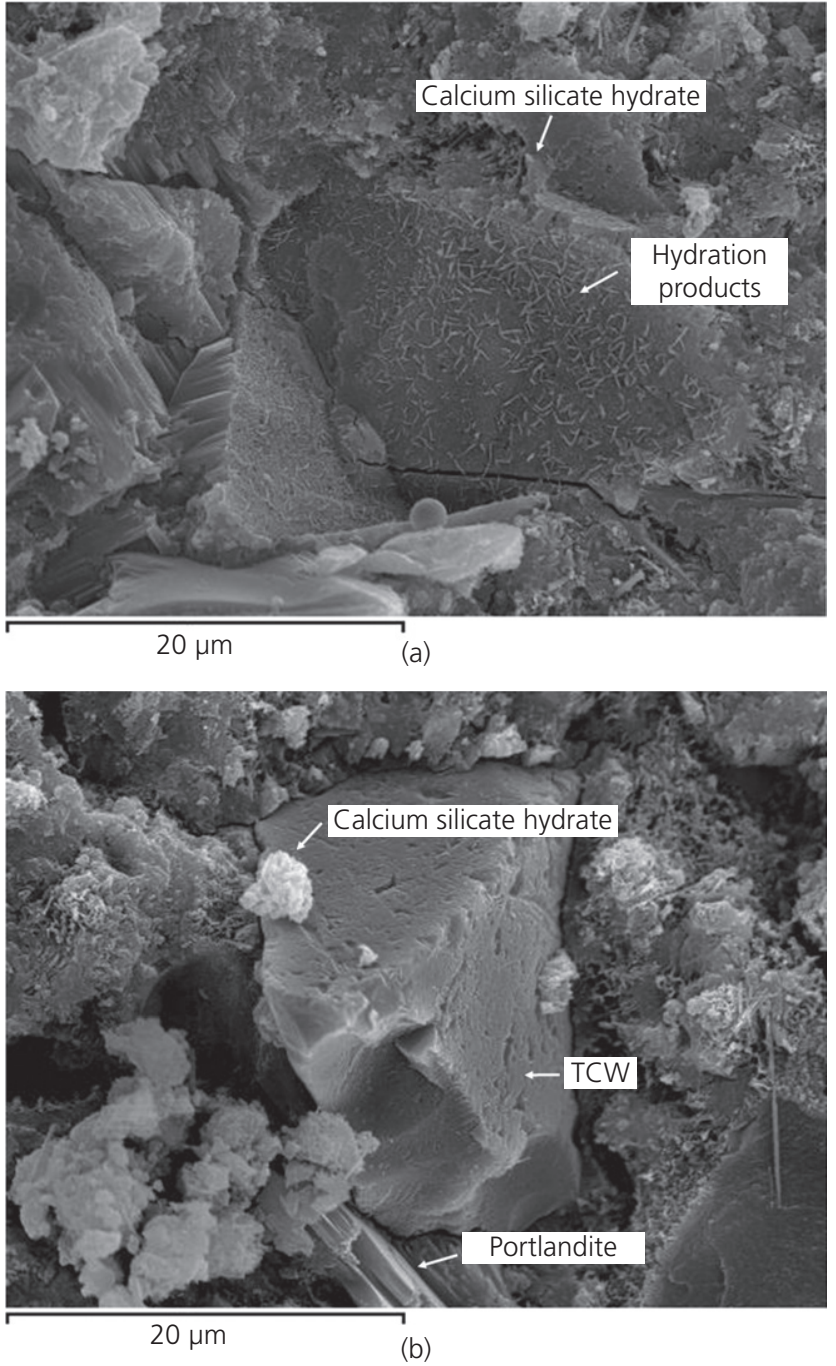

Figure 12. SEM images of pastes cured at $20^{\circ} \mathrm{C}$ for $90 \mathrm{~d}$ : (a) 25 wt\% TCW; (b) 50 wt\% TCW

\section{Scanning electron microscopy}

The microstructures of the pastes containing $25 \mathrm{wt} \%$ and $50 \mathrm{wt} \% \mathrm{TCW}$ as Portland cement substitute and cured for $28 \mathrm{~d}$ and $90 \mathrm{~d}$ are presented in Figures 11 and 12. The presence of ettringite needles, hexagonal plates of portlandite and calcium silicate hydrate amorphous products, previously identified by the XRD, FTIR and TGA, was corroborated by SEM. Similarly, unreacted TCW particles slightly covered by hydration products were observed (Figure 12).

\section{Conclusions}

This research has demonstrated the potential use of tile ceramic waste (TCW) to produce pozzolanic cement. The experimental study provided the following conclusions.

- The TCW composition is appropriate for reacting with the portlandite formed during Portland cement hydration to form cementing compounds through the pozzolanic reaction.

- The negative fixed lime values obtained at short curing ages denote an accelerated hydration process of Portland cement due to the particle effect conferred by the pozzolan. The positive values recorded after $90 \mathrm{~d}$ curing indicate that the reactivity of TCW with the Portland cement hydration products occurs mainly at long curing ages.

- The workability of the mortars containing TCW was similar to that presented by the control mortar without TCW.

- Additions within the range $15-35 \mathrm{wt} \%$ satisfy the strength activity index established by fly ash regulations, and are higher than $75 \%$ and $85 \%$ after $28 \mathrm{~d}$ and $90 \mathrm{~d}$ curing respectively.

\section{Acknowledgements}

The authors are grateful to the Spanish Ministry of Science and Innovation for supporting this study through project GEOCEDEM BIA 2011-26947, and also to FEDER funding.

\section{REFERENCES}

Alves AV, Vieira TF, Brito J and Correia JR (2014) Mechanical properties of structural concrete with fine recycled ceramic aggregates. Construction and Building Materials 64(\%): 103-113.

Ay N and Ünal M (2000) The use of waste ceramic tile in cement production. Cement and Concrete Research 30(?9:): 497-499.

Bezerra Cabral AE, Schalch V, Coitinho Dal Molin DC and Duarte Ribeiro JL (2010) Mechanical properties modeling of recycled aggregate concrete. Construction and Building Materials 24(\%9): 421-430.

Cyr M, Lawrence P and Ringot E (2005) Mineral admixtures in mortars. Quantification of the physical effects of inert materials on short-term hydration. Cement and Concrete Research 35(\%): 719-730.

Frías M, Villar E and Savastano H (2011) Brazilian sugar cane bagasse ashes from the cogeneration industry as active pozzolans for cement manufacture. Cement and Concrete Composites 33(\%): 490-496.

Frías $M$, Savastano $H$, Villar E, Sánchez de Rojas $M I$ and Santos S (2012) Characterization and properties of blended cement matrices containing activated bamboo leaf wastes. Cement and Concrete Composites 34(\%?): 1019-1023.

García Ten FJ (2005) Descomposición Durante la Cocción del Carbonato Cálcico Contenido en el Soporte Crudo de los Azulejos. PhD thesis, Universitat Jaume I, Castelló, Spain (in Spanish).

GdE (Gobierno de España) (2010) Ministerio de Fomento de España, Catálogo de Residuos Utilizables en Construcción. See http://www.cedexmateriales.vsf.es/view/ 


\section{PROOFS}

archivos/residuos/447.pdf (accessed 01/03/2014)

(in Spanish).

Q21 Heidari A and Takavoli D (2013) A study of the mechanical properties of ground ceramic powder concrete incorporating nano-SiO $\mathrm{S}_{2}$ particles. Construction and

Q20 Building Materials 38(??): 255-264.

INE (Instituto Nacional de Estadística) (2015) Estadísticas Sobre Medio Ambiente. Encuesta Sobre Generación de Residuos en el Sector Servicios y Construcción. See http://www.ine.es/prensa/np801.pdf (accessed 01/02/2015)

Q22 (in Spanish).

Lavat AE, Trezza MA and Poggi M (2009) Characterization of ceramic roof tile wastes as pozzolanic admixture. Waste

Q23 Management 29(ㅇ): 1666-1674.

Lee TC and Li ZS (2010) Conditioned MSWI ash-slag-mix as a replacement for cement in cement mortar. Construction

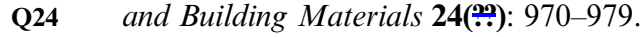

Medina C, Frías M and Sánchez de Rojas MI (2012a)

Microstructure and properties of recycled concretes using ceramic sanitary ware industry waste as coarse aggregate. Construction and Building Materials 31(우):

Q25 112-118.

Medina C, Frías M, Sánchez de Rojas MI, Thomas C and Polanco JA (2012b) Gas permeability in concrete containing recycled ceramic sanitary ware aggregate. Construction and Building Materials 37(\%):

Q26 597-605.

Medina C, Banfill PFG, Sánchez de Rojas MI and Frías M (2013a) Rheological and calorimetric behaviour of cements blended with containing ceramic sanitary ware and construction/demolition waste. Construction and Building

Q27 Materials 40(\%9): 822-831.

Medina C, Sánchez de Rojas MI and Frías M (2013b) Properties of recycled ceramic aggregate concretes: water resistance. Cement and Concrete Composites 40(99):

Q28 21-29.

Meyer C (2009) The greening of the concrete industry.

Q29 Cement and Concrete Composites 31(99): 601-605.

Monfort E, Mezquita A, Mallol G, Granel R and Vaquer E (2011) Guía de Ahorro Energético en el Sector de Baldosas Cerámicas. Instituto de Tecnología Cerámica, Agencia Valenciana de la Energía, Aepósito Legal

Q30 V-2078-2011 (in Spanish).

Naceri A and Hamina MC (2009) Use of waste brick as a partial replacement of cement in mortar. Waste

Q31 Management 29(\%): 2378-2384.

Parande AK, Ramesh Babu B, Pandi K, Karthikeyan MS and Palaniswamy N (2011) Environmental effects on concrete using ordinary and pozzolana Portland cement. Construction and Building Materials 25(\%):

Q32 288-297.

Payá J, Monzó J and Borrachero MV (1999) Fluid catalytic cracking catalyst residue (FC3R): an excellent mineral by-product for improving early-strength development of cement mixtures. Cement and Concrete Research 29(99:): 1773-1779.

Payá J, Borrachero MV, Monzó J, Peris-Mora E and Bonilla M (2002) Long term mechanical strength behaviour in fly ash/Portland cement mortar prepared using processed ashes. Journal of Chemical Technology and Biotechnology 77(9): 336-344.

Payá J, Monzó J, Borrachero MV and Velázquez S

(2003) Evaluation of the pozzolanic activity of fluid catalytic cracking catalyst residue (FC3R). Thermogravimetric analysis studies on FC3R-Portland cement pastes. Cement and Concrete Research 33(?:?): 603-609.

Pereira de Oliveira LA, Castro Gomes JP and Santos PMS (2012) The potential pozzolanic activity of glass and red-clay ceramic waste as cement mortars components. Construction and Building Materials 31(\%9): 197-203.

Puertas F, García D, íaz I, Palacios M et al. (2010) Clinkers and cements obtained from raw mix containing ceramic waste as a raw material. Characterization, hydration and leaching studies. Cement and Concrete Composites 32(\%9:): 175-186.

Reig L, Tashima M, Soriano L et al. (2013a) Alkaline activation of ceramic waste materials. Waste and Biomass Valorization 4(\%): 729-736.

Reig L, Tashima MM, Borrachero MV et al. (2013b) Properties and microstructure of alkali-activated red clay brick waste. Construction and Building Materials 43(99): 98-106.

Reig L, Soriano L, Borrachero MV, Monzó J and Payá J (2014) Influence of the activator concentration and calcium hydroxide addition on the properties of alkali-activated porcelain stoneware. Construction and Building Materials

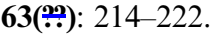

Senthamarai RM, Manoharan PD and Gobinath D (2011) Concrete made from ceramic industry waste: durability properties. Construction and Building Materials 25(⿳9冖9): 2413-2419.

Shi C, Fernández Jiménez A and Palomo A (2011) New cements for the 21st century: the pursuit of an alternative to Portland cement. Cement and Concrete Research 41(\%?): $750-763$.

Silva J, de Brito J and Veiga R (2008) Fine ceramics replacing cement in mortars. Partial replacement of cement with fine ceramics in rendering mortars. Materials and Structures 41(99): 1333-1344.

Stock D (2014) World production and consumption of ceramic tiles. Tile Today 85: 54-62. See www. infotile.com/publications (accessed 01/01/2015).

Sun Z, Cui H, An H et al. (2013) Synthesis and thermal behavior of geopolymer-type material from waste ceramic. Construction and Building Materials 49(\%)): 281-287.

Tashima MM, Soriano L, Monzó J et al. (2014) New method to assess the pozzolanic reactivity of mineral 
Advances in Cement Research Volume 00 Issue 00
Ceramic tiles waste as replacement

material in Portland cement

Mas, Monzó, Payá, Reig and Borrachero

\section{PROOFS}

admixtures by means of $\mathrm{pH}$ and electrical conductivity measurements in lime:pozzolan suspensions. Materiales de Construcción 64(ج)): e032, http://dx.doi.org/10.3989/mc.

\section{Q45 2014.00914.}

Yu P, Kirkpatrick RJ, Poe B, McMillan PF and Cong X

(1999) Structure of calcium silicate hydrate (C-S-H): near-, mid-, and far-infrared spectroscopy. Journal of the American Ceramic Society 82(?9?): 742-748.

Zanelli C, Raimondo M, Guarini G and Dondi M (2011)

The vitreous phase of porcelain stoneware: composition, evolution during sintering and physical properties. Journal of Non-Crystalline Solids 357(色): 3251-3260.

\section{WHAT DO YOU THINK?}

To discuss this paper, please submit up to 500 words to the editor at journals@ice.org.uk. Your contribution will be forwarded to the author(s) for a reply and, if considered appropriate by the editorial panel, will be published as a discussion in a future issue of the journal. 


\section{QUERY FORM}

\section{Institution of Civil Engineers (ICE)}

\section{Journal Title: ADVANCES IN CEMENT RESEARCH (ADCR) Article No: 1500021}

AUTHOR: The following queries have arisen during the editing of your manuscript. Please answer the queries by making the requisite corrections at the appropriate positions in the text.

\begin{tabular}{|c|c|c|}
\hline Query No. & Nature of Query & Author's Response \\
\hline Q1 & Please give job title/position of ALL authors & Modified in Q1 \\
\hline Q2 & Medina et al. 2012a or $2012 b$, or both? & Both \\
\hline Q3 & Medina et al. $2013 \mathrm{a}$ or $2013 \mathrm{~b}$, or both? & Both \\
\hline Q4 & Reig et al. 2013a or $2013 \mathrm{~b}$ or both? & Both \\
\hline Q5 & $\begin{array}{l}\text { Spanish National Institute of Statistics (2013): should this refer- } \\
\text { ence be INE } 2015 \text { ? }\end{array}$ & INE, 2013 \\
\hline Q6 & $\begin{array}{l}\text { Please add details of UNE EN 196-2 to reference list and give } \\
\text { correct citation here }\end{array}$ & Added in list and cita \\
\hline Q7 & EDTA defined as Ethylenediaminetetraacetic acid: is this OK? & Yes \\
\hline Q8 & $\begin{array}{l}\text { Please add details of UNE EN 196-1 to reference list and give } \\
\text { correct citation here }\end{array}$ & Added in list and citat \\
\hline Q9 & $\begin{array}{l}\text { Please add details of UNE } 83811 \text { to reference list and give correct } \\
\text { citation here }\end{array}$ & Added in list and citat \\
\hline Q10 & not sure what is meant by "closer to the unit": please clarify & 'the unit' replaced by \\
\hline Q11 & $\begin{array}{l}\text { Heidari et al. } 2013 \text { is not in reference list. Please give full } \\
\text { details of this work or advise changes to citation (Heidari } \\
\text { and Takavoli?) }\end{array}$ & $\begin{array}{l}\text { Change to Heidari and } \\
\text { Takavoli }\end{array}$ \\
\hline Q12 & Should this be Heidari and Takavoli? & Yes \\
\hline Q13 & $\mathrm{OH}$ changed to $-\mathrm{OH}$, as above: is this $\mathrm{OK}$ ? & Yes \\
\hline Q14 & Please supply issue number & 08 \\
\hline Q15 & Please supply issue number & 03 \\
\hline Q16 & Please supply issue number & 04 \\
\hline Q17 & Please supply issue number & 04 \\
\hline Q18 & Please supply issue number & 04 \\
\hline Q19 & Please supply issue number & 09 \\
\hline Q20 & $-->$ Year changed tc & 2013, when study was d \\
\hline Q21 & $\begin{array}{l}\text { Heidari and Takavoli is not cited. Please add citation to main text } \\
\text { or confirm item can be removed from list }\end{array}$ & $\begin{array}{l}\text { Citation has been modif } \\
\text { in the text }\end{array}$ \\
\hline Q22 & $\begin{array}{l}\text { INE } 2015 \text { is not cited. Please add citation to main text or confirm } \\
\text { item can be removed from list }\end{array}$ & $\begin{array}{l}\text { INE } 2013 \text { has been cited } \\
\text { in the text }\end{array}$ \\
\hline Q23 & Please supply issue number & 05 \\
\hline Q24 & Please supply issue number & 06 \\
\hline Q25 & Please supply issue number & 06 \\
\hline Q26 & Please supply issue number & 12 \\
\hline
\end{tabular}




\begin{tabular}{|l|l|l|} 
Q27 & Please supply issue number & 03 \\
\hline Q28 & Please supply issue number & 07 \\
\hline Q29 & Please supply issue number & 08 \\
\hline Q30 & $\begin{array}{l}\text { Please give name and location (town/city and country) of organisa- } \\
\text { tion issuing report }\end{array}$ & Valencia, Spain \\
\hline Q31 & Please supply issue number & 08 \\
\hline Q32 & Please supply issue number & 01 \\
\hline Q33 & Please supply issue number & 11 \\
\hline Q34 & Please supply issue number & 03 \\
\hline Q35 & Please supply issue number & 04 \\
\hline Q36 & Please supply issue number & 06 \\
\hline Q37 & Please supply issue number & 03 \\
\hline Q38 & Please supply issue number & 04 \\
\hline Q39 & Please supply issue number & 06 \\
\hline Q40 & Please supply issue number & 07 \\
\hline Q41 & Please supply issue number & 05 \\
\hline Q42 & Please supply issue number & 07 \\
\hline Q43 & Please supply issue number & 08 \\
\hline Q44 & Please supply issue number & 12 \\
\hline Q45 & Please supply issue and page numbers & 316, pages 1-12 \\
\hline Q46 & Please supply issue number & 03 \\
\hline Q47 & Please supply issue number & 16 \\
\hline
\end{tabular}

